\title{
Leading approaches to using renewable power sources for improving national energy security
}

\author{
Evgeny Lisin \\ Department of Economics in Power Engineering and Industry \\ National Research University "Moscow Power Engineering Institute" \\ 14 Krasnokazarmennaya str., 111250, Moscow \\ Russian Federation \\ e-mail: lisinym@mpei.ru \\ Galina Kurdiukova \\ Department of Economics in Power Engineering and Industry \\ National Research University "Moscow Power Engineering Institute" \\ 14 Krasnokazarmennaya str., 111250, Moscow \\ Russian Federation \\ e-mail: kurdiukovagn@mpei.ru \\ Ekaterina Rukina \\ Department of Economics in Power Engineering and Industry \\ National Research University "Moscow Power Engineering Institute" \\ 14 Krasnokazarmennaya str., 111250, Moscow \\ Russian Federation \\ e-mail: rukinayi@mpei.ru
}

\begin{abstract}
Nowadays the main power sources extensively used by the humankind are represented by the various types of fossil fuels, first and most of all, by oil and gas. However, these sources have limited reserves that will be deploited within the next 100-200 years according to various estimates.

Unlike traditional power industry, power industry of renewable energy sources (RES) is not based on substance reserves, but on natural energy flows. These are wind flows, solar radiation, heat of the earth interior, etc. This paper focuses on the usage of the world's energy resources over the past 40 years and offers new solutions for employing the leading approaches for using renewables in otder to improve the energy security.

Based on the conducted structural analysis of the stored energy resources, the rationale for the use of renewable power sources considering national energy security is provided, and a model for their economic evaluation is proposed through the example of wind generation facilities.
\end{abstract}

\section{Introduction}

Power engineering technologies play crucial role in social and economic development, have significant impact on environmental pollution and living standards, and determine energy security in the system of national and economic security of the country.

The backbone of the power industry is energy resources represented by various types of energy carriers. The energy carriers are non-renewable and renewable power sources. The first group includes organic and inorganic fuel. Organic fuel is coal, natural and associated gas, oil (oil residue), oil shale, peat, firewood and biofuel. Inorganic fuel forms nuclear fuel. The second group includes hydropower, solar power, power of wind, solids (hydrothermal and petrothermal), tidal waves and sea currents (Strielkowski et al. 2013; Lisin et al. 2015).

Energy security determines protection state of the economy and consumers from the external and internal threats to stable fuel and energy supply failure. In the market conditions such state is achieved by ensuring lack free resource supply, consumer availability of energy products and its production economic profitability, as well as availability of technologies ensuring reliable and efficient operation of power facilities with the existing environmental restrictions (Lisin et al. 2018; Bilgen 2014).

Above all, energy security is characterized by sufficiency and economic availability of energy resources. Therefore, the issues of production, distribution and consumption of resources step forward in the modern world economy. Territories with concentrated resources often become areas for geopolitical conflicts, and extraction and supply of resources is a matter of dispute for not only business entities, but entire countries (Bompard et al. 2017; Ang et al. 2015). 
Production and consumption of resources constantly increases as the planet population growth. At the same time it is already obvious that reserves of organic resources are quite limited, and over the medium term economically feasible volumes for production will be exhausted in many countries. At the same time, the peak of nuclear power industry development has passed, and its percentage is gradually decreasing due to the fact that nuclear energy does not fit quite good into the modern economic conditions showing rapid change. Nuclear power plants are too expensive, have long construction period, and issues regarding radioactive waste disposal have not been solved yet. And also often choosing peaceful atom as a power source is a political decision which faces great difficulties while being made.

With reference to the above mentioned, it becomes obvious that only development of renewable power sources can meet the power needs of countries over the long term. So the greatest challenge for ensuring sustainable economic development is the development of economic mechanisms and integration technologies of production facilities based on renewable energy resources into existing power systems.

\section{Analysis of the dynamics of world production and consumption of primary energy}

The world's primary power sources production made 13,113.00 million tons of oil equivalent in 2016, that is over 2 times higher of the same parameter in 1975. Percentage of fossil fuel, in particular oil, coal and natural gas is still significant, however, compared to 1975, the following noticeable changes took place (IEA 2012; 2016; 2018):

- $\quad$ oil percentage decreased 1.5 times;

- coal, natural gas, nuclear energy and hydro resources percentage increased;

- percentage of other power sources increased 10 times, including geothermal energy, solar and wind energy, but it is still low $-1 \%$.

The final consumption of resources in 2016 made 8,918.00 million tons of oil equivalent. Various types of fossil fuel prevail in final consumption as well as production, oil in particular, there are no hydro resources and nuclear energy, as soon as these types of resources are consumed for electrical power production. Compared to 1975 when final consumption of resources made 4,674.00 million tons of oil equivalent, the following structural changes took place (IEA 2012; IEA 2018; or EIA 2016):

- $\quad$ oil percentage decreased from $48.1 \%$ to $40.8 \%$;

- $\quad$ electric power and other power sources percentage increased two times;

- $\quad$ biofuel and wastes percentage decreased.

One can estimate the level of economic development of a country and its position in the world economy by the level of production and consumption, export and import of energy resources, as well as by specific values of these indicators with regard to population and GNP. The specific value of consumed power sources per GNP unit in developed countries is relatively low, which indicates a high technological and energy efficiency of production, while a significant percentage of resources and electric power is consumed by households.

Russia is the third largest producer of energy resources, but almost half of all the resources are exported. Resource consumption per GNP unit is very high, over 4 times higher than in the US, and 8 times higher than in Germany and Japan. Electric power consumption per capita is at average level - lower than in Canada and the US, but much higher than in densely-populated China and India (see Table 1).

Table 1. The main indicators of power industry development in some countries (2016)

\begin{tabular}{|c|c|c|c|c|c|c|c|}
\hline$\dot{0}$ & $\begin{array}{l}\stackrel{己}{\Xi} \\
\Xi \\
0\end{array}$ & 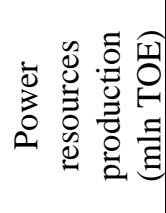 & 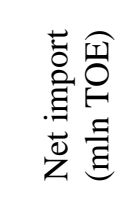 & 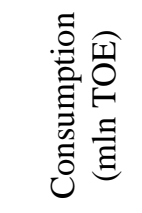 & 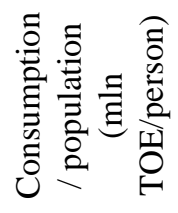 & 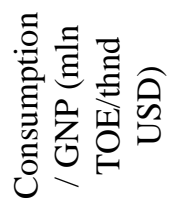 & 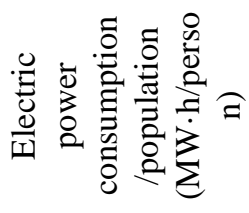 \\
\hline 1 & China & $2,432.50$ & 378.62 & $2,727.73$ & 2.03 & 0.65 & 0.27 \\
\hline 2 & USA & $1,784.77$ & 457.62 & $2,191.19$ & 7.02 & 0.17 & 13.23 \\
\hline 3 & Russia & $1,314.88$ & -571.81 & 730.97 & 5.15 & 0.77 & 6.53 \\
\hline 4 & India & 540.94 & 213.46 & 749.45 & 0.60 & 0.57 & 0.67 \\
\hline 5 & Canada & 409.03 & -158.46 & 251.85 & 7.30 & 0.20 & 16.41 \\
\hline 6 & Germany & 124.19 & 199.04 & 311.77 & 3.81 & 0.10 & 7.08 \\
\hline 7 & Japan & 51.67 & 421.10 & 461.47 & 3.61 & 0.10 & 7.85 \\
\hline
\end{tabular}

Source: Own results based on (IEA 2012; EIA 2016) 
For the period of 1975 to 2016 in the structure of primary resources used for power production percentage of oil decreased significantly, percentage of coal, natural gas and nuclear fuel increased, as well as percentage of other power sources, such as geothermal, solar, wind energy and biofuel. The main electric power production resource is natural gas; in China, USA, India and Germany - coal, and in Canada - rivers' energy (Table 2).

Table 2. Electric power production in some countries (2016)

\begin{tabular}{|l|l|l|l|l|l|l|l|}
\hline $\begin{array}{c}\text { Country/ } \\
\text { Production (GWh) }\end{array}$ & \multicolumn{1}{|c|}{ China } & \multicolumn{1}{|c|}{ USA } & \multicolumn{1}{|c|}{ Russia } & \multicolumn{1}{|c|}{ Candia } & Gapan \\
\hline Coal and peat & 3723244 & 1875413 & 164348 & 714954 & 76364 & 271865 & 281143 \\
\hline Oil & 7857 & 39524 & 27362 & 12223 & 6531 & 6608 & 153336 \\
\hline Gas & 84022 & 1045254 & 519202 & 108534 & 62111 & 83630 & 373957 \\
\hline Biofuel & 31500 & 53703 & 35 & 28724 & 10610 & 32849 & 28827 \\
\hline Waste & 10770 & 23789 & 2742 & 0 & 164 & 11156 & 8123 \\
\hline Nuclear power & 86350 & 821405 & 172941 & 33286 & 93589 & 107971 & 101761 \\
\hline Hydro & 698945 & 344679 & 167608 & 130668 & 375797 & 23514 & 91709 \\
\hline Geothermal & 153 & 17892 & 522 & 0 & 0 & 19 & 2676 \\
\hline Solar & 2533 & 5260 & 0 & 104 & 260 & 19340 & 5160 \\
\hline Wind & 70331 & 893 & 5 & 23837 & 10187 & 48883 & 4559 \\
\hline Tidal & 11 & 120854 & 0 & 0 & 26 & 0 & 0 \\
\hline Other & 0 & 905 & 0 & 0 & 1350 & 2830 & 0 \\
\hline Total & 4715716 & 4349571 & 1054765 & 1052330 & 636989 & 608665 & 1051251 \\
\hline
\end{tabular}

Source: Own results based on (IEA 2012; EIA 2016)

In the world's electric power consumption structure of 1975 to 2016 significant changes took place as well: percentage of industry and transport has decreased, percentage of energy consumed by households, commercial and public companies and agriculture has increased (Table 3). The greater percentage of electric power in Russia is consumed in the field of industry, while in the USA and Japan - households, as well as commercial and public companies.

Table 3. Electric power consumption in some countries (2016)

\begin{tabular}{|l|l|l|l|l|l|l|l|}
\hline Consumption $(\mathrm{GWh})$ & \multicolumn{1}{|c|}{ China } & \multicolumn{1}{|c|}{ USA } & \multicolumn{1}{c|}{ Russia } & \multicolumn{1}{c|}{ India } & \multicolumn{1}{c|}{ Canada } & \multicolumn{1}{c|}{ Germany } & \multicolumn{1}{c|}{ Japan } \\
\hline Industry & 2654345 & 898592 & 332818 & 346469 & 205786 & 230655 & 279377 \\
\hline Transport & 46340 & 7672 & 90355 & 14327 & 3852 & 16600 & 18568 \\
\hline Households & 562006 & 1422801 & 130889 & 170034 & 153031 & 136600 & 290208 \\
\hline $\begin{array}{l}\text { Commercial and } \\
\text { public companies }\end{array}$ & 220525 & 1328057 & 159631 & 69266 & 146778 & 128662 & 345285 \\
\hline $\begin{array}{l}\text { Agriculture and } \\
\text { forestry }\end{array}$ & 101290 & 0 & 14851 & 133660 & 9446 & 9000 & 858 \\
\hline Other & 277990 & 132754 & 0 & 39802 & 0 & 0 & 5119 \\
\hline Total & 3862496 & 3789876 & 728824 & 773558 & 518893 & 521517 & 939415 \\
\hline
\end{tabular}
Source: Own results based on (IEA 2012; EIA 2016)

Electric power price also varies considerably in different countries across the world depending on the pricing system approved, regulation system applied, country's own primary resources availability and energy balance structure (Strielkowski et al. 2017; Vegera et al. 2018). Common specific feature is more expensive electric power for households than for industry in developed countries, while in Russia electric power for population is cheaper (Table 4).

Table 4. Electric power price in some countries (2016)

\begin{tabular}{|l|l|l|}
\hline \multicolumn{1}{|c|}{ Country } & Electric power for industry (USD/MWh) & Electric power for households (USD/MWh) \\
\hline Japan & 194.27 & 276.76 \\
\hline Germany & 148.71 & 338.75 \\
\hline Great Britain & 134.17 & 220.74 \\
\hline France & 116.33 & 174.77 \\
\hline Russia & 105.21 & 55.11 \\
\hline Denmark & 104.15 & 383.43 \\
\hline Finland & 103.89 & 194.87 \\
\hline USA & 66.98 & 118.83 \\
\hline
\end{tabular}

Source: Own results based on (IEA 2012; IEA 2018) 
Based on the data presented one can conclude that the highest price for electric power is peculiar for countries with less amount of own primary energy resources and production capacities. The power low price also is significantly affected by the country's energy policy with redistribution of electric power price between different groups of consumers as one of the tools.

\section{Economic aspects of the use of wind turbines in the country's power systems}

The capacity of wind turbines for commercial purpose has constantly increased from $50 \mathrm{~kW}$ to $7.5 \mathrm{MW}$ over the past 40 years (Yang et al. 2014; Tchakoua et al. 2014). Equipment design standards and certification procedures were implemented, which ensured significant increase of reliability and performance. Wind energy cost has decreased so much that in some cases has become competitive with traditional power sources (Fortov 2014; Hirth et al. 2015; Lisin et al. 2016; or Rogalev et al. 2018).

The wind power market growth was the strongest in the EU until 2008 and was expressed in increase of the generation facilities' installed capacity. However, China is the leader in terms of new capacities commissioning since 2008. The average annual growth in the wind power industry is about $27 \%$, the installed capacity is doubled every three years averagely. 83 countries in total use wind energy on a commercial basis nowadays. In 2016, the EU had about $41 \%$ of the world's installed capacity of wind power facilities, China $26 \%$, USA - 20\% (IEA 2016; Ketterer 2014).

The onshore wind power facilities dominate in the market due to significant amount of undeveloped onshore wind resources. However, the market of offshore wind generators is also gradually growing. The current market analysis based on researching projects at acceptance, construction stage or the one having obtained financing, shows that nearly $85 \mathrm{GW}$ of new capacity can be commissioned within the next 5 years. Seems like the offshore market will be moved by Great Britain and Germany. China also becomes more interested in the offshore power industry (Xiao et al. 2015).

The total installed capacity of wind power facilities in 2016 in Russia made 99.9 MW, or as low as $0.04 \%$ of the installed capacity of power plants in energy system. The largest power plants are Zelenogradskaya WDP in the Kaliningrad region with capacity of $5.1 \mathrm{MW}$, and Tyupkildy WDP in the Republic of Bashkortostan with capacity of 2.2 MW (Lombardi et al. 2016).

Having the economic aspects of the wind power industry considered, it is important to distinguish between cost for wind energy generation and the produced power's market price. Economic feasibility of wind energy depends on the comparison of these two variables: market price should exceed the cost price of electric power production.

The average estimated cost of electric power production within the entire life cycle of a power plant (LCOE) is the main indicator for describing and comparing power engineering projects (Pawel 2014; Lisin et al. 2016). For wind power industry this indicator represents the sum of all the costs of fully operating wind power system within the project life cycle with discounted cash flows.

A common practice is to equate design life cycle to economic cycle of a wind power system (Weitemeyer et al. 2015). A period of 20 years is often used for economic evaluation of wind power systems in the EU. It is assumed that wind turbines are maintained annually, and overhaul is carried out with replacement of the main parts once in 10 years.

A wind power project capital costs can be divided into the following main categories:

- $\quad$ turbine price: including blades, tower and transformer;

- construction works: including cost of site and tower foundation preparation;

- network connection costs: may include transformers and substations, as well as local distribution or trunk lines;

- other costs: may include construction of buildings, management systems, consulting, etc.

Table 5. Capital investments in wind power facilities

\begin{tabular}{|l|l|l|}
\hline \multicolumn{1}{|c|}{ Cost centers } & \multicolumn{1}{|c|}{ Onshore } & \multicolumn{1}{c|}{ Offshore } \\
\hline Capital investments, USD/kW & $1700-2450$ & $3300-5000$ \\
\hline Wind turbine cost percentage, $\%$ & $65-84$ & $30-50$ \\
\hline Network connection cost percentage, $\%$ & $9-14$ & $15-30$ \\
\hline Construction works cost percentage, $\%$ & $4-16$ & $15-25$ \\
\hline Other expenses percentage, $\%$ & $4-10$ & $8-30$ \\
\hline
\end{tabular}

Source: Own results

The most expensive turbine components are rotor blades, tower and gearbox. These three components together make $50-60 \%$ of the turbine cost. Generator, transformer and converter make about $13 \%$ of the turbine cost. The turbine cost in general is $64-84 \%$ of total expenses, all the rest is cost of network connection, 
construction works and other expenses. Actually, the size and structure of capital costs varies significantly depending on country and project. Typical data on capital costs for onshore and offshore wind power facilities is presented in Table 5 above.

Network connection costs can also vary significantly depending on the country and nature of expenses. For instance, in some systems a network company bears all the costs of networks upgrading for WPS connection, in other systems the WPS owner bears such costs. Network connection costs (including electrical works, power lines and connection point) usually make $11-14 \%$ of the total cost of onshore and $15-30 \%$ of offshore wind power unit.

Operating costs may include expenses for wind power unit insurance, taxes and land rent fees, as well as maintenance costs. Maintenance costs make a significant percentage of the average energy cost - usually 20 to $25 \%$.

For the wind energy market price estimation, the principle of saving (economy) is often used, which will be ensured as a result of wind energy use instead of the most probable alternative. Such economy is the result of reduced fuel consumption that could be consumed at traditional power plants. It can also be the result of reduced required total capacity of traditional power plants.

Equating the wind energy value to the costs only that have been avoided, leads to omission of significant environmental benefit from the calculations, obtained from the absence of harmful substances emission into atmosphere, particularly nitrogen oxides, sulfur and carbon (Dai et al. 2015; Nejat et al. 2015).

Transformation of wind power benefit for environment into monetary form is quite a complicated task. Nevertheless, this solution is required for raising the economic efficiency of investment projects for wind generation facilities construction.

The above-mentioned task is solved by state regulation as a rule. The cost of alternative measures aimed at reduction of emissions (such as gas scrubbers in coal mines) and the money value of emissions that have been avoided are taken into account. According to the estimates obtained, the effect of monetary benefit on the environment is approximately $50 \%$ of the fuel consumption reduction and capacity commissioning.

\section{Conclusions}

The national energy security is determined by the required amount and economic availability of energy resources. Production and consumption of resources is constantly increasing in conditions of population growth. Therefore, issues of production, distribution and consumption of resources step forward in the modern world economy.

Reserves of organic resources are obviously quite limited, and in the midterm their economically feasible production volumes will be exhausted in many countries. At the same time the peak of nuclear power industry development has passed, and its percentage is gradually decreasing due to the fact that nuclear power does not fit into the modern rapidly changing economic conditions.

Analysis of change in energy resources production structure over the past 40 years has shown that despite the fact that fossil fuel still remains the main energy carrier, percentage of other power sources has increased ten times, with the wind and solar energy highlighted as the first ones.

Various kinds of fossil fuel prevail in the end-user consumption, as well as in production. At the same time importance of consumed power sources per GNP unit has significantly decreased in many countries due to production technological and energy efficiency improvement, as well as due to changes in consumption structure - percentage of industry and transport has decreased, percentage of energy consumed by households, commercial and public companies, and agriculture has increased.

The end-user power cost for a consumer has also increased. And its significance varies greatly depending on the country's pricing system and the country's own primary resources availability. A common feature is the fact that in developed countries electric power for households is more expensive than for industry, while in developing countries the situation is opposite. In general, the highest cost of electric power corresponds to countries with small amount of own primary energy resources and production capacities.

Over the past 40 years of the wind power industry development the wind power cost for a consumer has significantly decreased, and currently in some countries it competes with traditional power sources with no government subsidies. The developed economic model of wind power cost formation shows that the main limitations for its wide application are high costs of connection to the electric network and ensuring the established operating modes of the power system. Moreover, transportation costs are much higher during construction of offshore wind power units. These costs are unlikely to decrease in the near future due to lack of specialized vessels and cranes.

Particularly important issue is wind power market value assessment. There are two types of added value that can be formed by applying wind power:

- based on prevention of fossil fuel expenses, 
- $\quad$ based on environmental benefits, which can be converted into money.

Issue of transformation of wind power environmental benefit into money has not yet been solved, and it is currently ensured by state regulation means. Nevertheless, it is necessary to solve it for the purpose of improving the economic efficiency of investment projects for wind generation facilities construction. It should be taken into account that nowadays wind generation is widespread mostly in the countries offering various incentives for its development in market and providing significant state support for its development at various levels. At the same time the wind speed potential that can be possibly used for commercial purposes, is quite average compared to other countries.

\section{Acknowledgements}

This paper was supported by the Ministry of Education and Science of the Russian Federation, research project No. 26.9593.2017/8.9.

\section{References}

Ang BW, Choong WL, Ng TS (2015) Energy security: Definitions, dimensions and indexes. Renewable and Sustainable Energy Reviews 42: 1077-1093. doi: 10.1016/j.rser.2014.10.064

Bilgen S (2014) Structure and environmental impact of global energy consumption. Renewable and Sustainable Energy Reviews 38: 890-902. doi: 10.1016/j.rser.2014.07.004

Bompard E, Carpignano A, Erriquez M, Grosso D, Pession M, Profumo F (2017) National energy security assessment in a geopolitical perspective. Energy 130: 144-154. doi: 10.1016/j.energy.2017.04.108

Dai K, Bergot A, Liang C., Xiang WN, Huang Z (2015) Environmental issues associated with wind energy - A review. Renewable Energy 75: 911-921. doi: 10.1016/b978-0-12-809451-8.00022-9

EIA (2016) International energy outlook 2016 with projections to 2040. https://www.eia.gov/outlooks/ieo/pdf/0484\%282016\%29.pdf Accessed 20 July 2018

Fortov VE (2014) The current status of the development of renewable energy sources worldwide and in Russia. Thermal engineering 61(6): 389-398. doi: 10.1134/s0040601514060020

Hirth L, Ueckerdt F, Edenhofer O (2015) Integration costs revisited-An economic framework for wind and solar variability. Renewable Energy 74: 925-939. doi: 10.1016/j.renene.2014.08.065

IEA (2012) Annual Energy Review 2011. https://www.eia.gov/totalenergy/data/annual/pdf/aer.pdf Accessed 20 July 2018

IEA (2018) World Energy Statistics and Balances (database). https://www.oecdilibrary.org/content/collection/enestats-data-en Accessed 20 July 2018

Ketterer JC (2014) The impact of wind power generation on the electricity price in Germany. Energy Economics 44: 270-280. doi: 10.1016/j.eneco.2014.04.003

Lisin E, Kurdiukova G, Strielkowski W (2016) Economic prospects of the power-plant industry development in Russia. Journal of International Studies 9(3):178-190. doi: 10.14254/2071-8330.2016/9-3/14

Lisin E, Rogalev A, Strielkowski W, Komarov I (2015) Sustainable modernization of the Russian power utilities industry. Sustainability 7(9):11378-11400. doi: 10.3390/su70911378

Lisin E, Shuvalova D, Volkova I, Strielkowski W (2018) Sustainable development of regional power dystems and the consumption of electric energy. Sustainability 10(4):1111-1121. doi: 10.3390/su10041111

Lombardi P, Sokolnikova T, Suslov K, Voropai N, Styczynski ZA (2016) Isolated power system in Russia: A chance for renewable energies? Renewable Energy 90: 532-541. doi: 10.1016/j.renene.2016.01.016

Nejat P, Jomehzadeh F, Taheri MM, Gohari M, Majid MZ (2015) A global review of energy consumption, CO 2 emissions and policy in the residential sector (with an overview of the top ten $\mathrm{CO} 2$ emitting countries). Renewable and sustainable energy reviews 43: 843-862. doi: 10.1016/j.rser.2014.11.066 
Pawel I (2014) The cost of storage-how to calculate the levelized cost of stored energy (LCOE) and applications to renewable energy generation. Energy Procedia 46:68-77. doi: 10.1016/j.egypro.2014.01.159

Rogalev A, Komarov I, Kindra V, Zlyvko O (2018) Entrepreneurial assessment of sustainable development technologies for power energy sector. Entrepreneurship and Sustainability Issues 6(1):429-445. doi: 10.9770/jesi.2018.6.1(26)

Strielkowski W, Krška Š, Lisin E (2013) Energy economics and policy of renewable energy sources in the European Union. International Journal of Energy Economics and Policy 3(4):333-340.

Strielkowski W, Lisin E, Astachova E (2017) Economic sustainability of energy systems and prices in the EU. Entrepreneurship and Sustainability Issues 4(4):591-600. doi: 10.9770/jesi.2017.4.4(14)

Tchakoua P, Wamkeue R, Ouhrouche M, Slaoui-Hasnaoui F, Tameghe TA, Ekemb G (2014) Wind turbine condition monitoring: State-of-the-art review, new trends, and future challenges. Energies 7(4):2595-2630. doi: 10.3390/en7042595

Vegera S, Malei A, Trubovich R (2018) Accounting development of natural resources in organizations carrying out the disposal of municipal waste and biogas extraction in the context of the "green" economy, Entrepreneurship and Sustainability Issues 6(1):211-225. doi: 10.9770/jesi.2018.6.1(14)

Xiao L, Wang J, Dong Y, Wu J (2015) Combined forecasting models for wind energy forecasting: A case study in China. Renewable and Sustainable Energy Reviews 44: 271-288. doi: 10.1016/j.rser.2014.12.012

Yang W, Tavner PJ, Crabtree CJ, Feng Y, Qiu Y (2014) Wind turbine condition monitoring: technical and commercial challenges. Wind Energy 17(5): 673-693. doi: 10.1002/we.1508 